\title{
Optimization of the Implementation of Village Government in Indonesia
}

\author{
R. Setiawan, E. Melinda \\ University of Bandar Lampung \\ Pagar Alam No. 29 Labuhan Ratu, Lampung, Indonesia, 35142
}

\begin{abstract}
The issuance of Law of the Republic of Indonesia No. 6 of 2014 concerning Villages, positioning villages as the spearhead of national development. The existence of a village law also provides clarity about the position and the authority of the village government in managing village household affairs. The regulation also regulates government policies regarding the allocation of village funds which allows them to be used to develop their potential. In addition, the village policy gives villages a source of funds and adequate authority to improve the welfare of the village community. Regulations that provide substantial authority and responsibility to villages must certainly be balanced with the implementation of village governments that are able to commit to running good governance. In implementing the policy, it turns out that there are still cases of misappropriation of the allocation of village funds by the village government apparatus. This paper will explain the analysis related to the importance of village governance in implementing the Law of the Republic of Indonesia No. 6 of 2014 using the rational bureaucracy theory put forward by M. Weber.
\end{abstract}

Keywords: village funds, village government, law, optimization, Indonesia

\section{Introduction}

The village is one of the components of nation development that has existed for a long time and has a significant influence on the development of a country, but it cannot be denied that village development in Indonesia is still very far from development priorities. In 2014 the Republic of Indonesia law on villages was issued which regulates several village autonomies rights. The existence of regulation will certainly give birth to the authority of the village government, this must be balanced with the implementation of a good and ideal village so that it can perform good service and administration in order to improve the welfare of the village community.

Regional autonomy is an appropriate policy to be implemented in Indonesia as a country consisting of various islands and there are various types of tribes in it 
which confirms that in a country rich in natural resources live various types or human characters with all its interests [1]. The collapse of the new order regime has given birth to a new system of decentralization or regional autonomy in which the government is no longer centralized in the Capital City of Indonesia and has been delegated in each region. In the era of regional autonomy, local governments have the authority to run the wheels of government in their respective regions [2]. Based on what is written in the Law of the Republic of Indonesia No. 23 of 2014 concerning Regional Government Article 1 paragraph 6 namely: "Regional Autonomy is the right, authority and obligation of autonomous regions to regulate and manage their own government affairs and the interests of local communities in the system of the Unitary State of the Republic of Indonesia" [3]. The article affirms that the regional government has the responsibility and authority in managing its own household affairs.

After a clear regulation on the granting of autonomy to the city and regency, now the village also gets the autonomous rights regulated in Law No. 6 of 2014 concerning Villages. Republic of Indonesia Law No. 6 of 2014 concerning Villages has the aim to provide clarity about the status of the existence of villages that had previously stood with a variety of diversity before and after the formation of the Unitary Republic of Indonesia [4]. In article 4 point e it is explained that the village regulation aims "to form a professional, efficient and effective, open and accountable village government" [5]. With the clarity of the rules governing the village and also the clarity about the status of the village, it can be assumed that the village has the authority to take care of the sustainability of the village with all the potential and diversity of the village.

Related to the above-mentioned points, the administration of village government needs to be considered. Good and ideal governance of the village will greatly affect the sustainability of the village, especially since it has also been explained about the authority of the village in relation to the budget of the village fund and the provision of village community services to improve the welfare of the village community. Village government can be described as a government organization, this organization has a function in the formulation of policies and coordination in the implementation of the task force of the village apparatus so that its existence has a significant role in the administration of governance in a village.

Regional autonomy is a concept that is closely related to the government management system where government is no longer centralized in the national capital, but some central government authority has been given to local governments with the intention that the government can run effectively and efficiently [6]. Regional autonomy or decentralization has now also penetrated into the domain of the village, where the village government is given recognition of its existence and can carry out some of the authorities and responsibilities that can be managed by the village government, for example are village government services and village fund management. The delegation of some authority to the village government is in accordance with Law No. 6 of 2014, it is necessary to have a good and responsible village government. Regarding the realization of an ideal village government, it was also emphasized in Law no. 6 of 2014 article 4 point e concerning the existence of 
village arrangements aimed at "forming a professional, efficient and effective, open and accountable village government" [4; 5].

The issuance of Law No. 6 of 2014 concerning Villages brought a breath of fresh air to the village community, moreover the regulation coincided with a policy regarding the launch of village funds given to the village government for the purposes of increasing development and welfare of the village community [7]. The policy is broadly based on the assumption that the government or village apparatus is better understood about the potential of the village, including with all the problems related to the social and economic life of the village community concerned. With this assumption, the village government should be able to use the authority given to develop the village by utilizing its potential, but it can also solve village problems or conflicts quickly, but the fact of implementation in the field is not as smooth as imagined. Indonesia Corruption Watch (ICW) in 2020 released 110 cases of corruption in village funds and allocation of village funds during 20192020. From the 110 cases, the perpetrators were carried out by village heads on average [8]. This proves that there is still a need for good bureaucracy to be upheld in the village government.

From the implementation of the village government, it turns out that there are many deviations carried out by the village government both village officials and village heads. According to the ICW data presentation, it was explained that there were a number of forms of corruption committed by the village government, namely embezzlement of funds, misuse of budget, abuse of authority, extortion, budget mark up, fictitious reports, budget cuts, and bribes [9]. Various violations of the village government are certainly not in accordance with the norms of an ideal bureaucratic order, especially on the concept of idealized bureaucracy according to Weber as written by Joko Widodo (President of the Republic of Indonesia) [10]. presents the characteristics of the bureaucracy put forward by Weber in a simpler form. First, there is division of labor and specialization. Second, impersonal orientation. Third, the hierarchy of authority. Fourth, rules and regulations. Fifth, career orientation. Sixth, efficiency. The fraud committed by the village government certainly has a major impact on the welfare of the village community. The authority that could have been used to improve the development and welfare of village communities actually added to the burden on the village community.

\section{Rational Theory of Bureaucracy (Weber)}

In carrying out village governance, the village head is assisted by the village apparatus or village bureaucrat in carrying out his administrative duties. Government is a system that must work well together in order to create an effective and efficient government so that it can carry out services and take care of the running of a good village government and be able to improve the welfare of the village community. Bureaucracy is a government organization that carries out the task of assisting the government in the administration of government or all matters relating to the implementation of a government both the central government and regional governments. According to a German sociologist, Max Weber, put forward 
a theory that bureaucracy is the most ideal form of organization in his opinion:

"Weber developed the concept of bureaucracy as a form of response to the environment at that time, which in his view would be overcome properly if the government developed an organization which he called legal-rational, namely a model of organization that came to be called bureaucracy" [11].

Weber saw that when administrative tasks expanded in the assignment, the division of labor was necessary as a necessity in carrying out increasingly complex administrative tasks.

In approaching bureaucracy, Max Weber, sees that bureaucracy is an organization in which the structure has been arranged in such a way that in the process the organization can run efficiently with the use of experts in it so as to provide more effective and maximum performance results. Max Weber argues that bureaucracy as a form of organization that is very efficient, which can be used more effectively for organizations that are more complex in nature, for example companies, government, military, with the increasing needs of modern society [12].

Before looking deeper into bureaucratic theory, Weber compiled a proposition regarding the preparation of a system of legal authority, namely [12; 11]: First, official duties are organized according to continuous rules. Second, the tasks are divided according to fields which are distinguished according to their respective functions complemented by the conditions of authority and sanctions. Third, positions are arranged in a hierarchical manner, control rights and complaints among them in detail. Fourth, the rules in accordance with the work are directed both technically and legally. Fifth, organizational resources are very different from those from members as private individuals. Sixth, the holder of the position is not in accordance with his position. Seventh, administration is based on written documents. Eighth, the legal authority system can take many forms, but seen from the original form is within the bureaucratic administrative staff.

Joko Widodo (President of the Republic of Indonesia) presents the characteristics of the Bureaucracy put forward by Weber in a simpler form. First, there is division of labor and specialization. Second, impersonal orientation. Third, hierarchy of authority. Fourth, rules and regulations. Fifth, career orientation. Sixth, efficiency [10]. With a variety of characteristics or characteristics about the bureaucratic model, the bureaucracy is considered a very effective and efficient organization with such a division. The ideal type of Weber's bureaucracy seems difficult to implement in real life. Bureaucracy according to Weber is an ideal type, because in its pure form it is intangible in a society, because formal organizations that are manifested in society only approach the ideal type in different degrees from one another [13].

\section{Implementation of Village Governance}

The granting of authority over villages that has been clearly regulated in Law No. 6 of 2016 is not just giving authority that can be interpreted as the transfer of power but is a responsibility that must also be implemented in improving welfare. Moreover, the allocation of village funds with no small value, of course, the village 
government must be able to manage them well and efficiently in order to carry out village development for the welfare of the village community. To carry out these duties and responsibilities an ideal form of village government bureaucratic organization is needed [14].

There are many opinions or elaborations on the ideal bureaucratic specifications according to Weber. Weber interpreted that bureaucracy is the ideal type of organization and the ideal bureaucracy has several characteristics, namely: First, there is division of work and specialization. Second, impersonal orientation. Third, there is a hierarchy of authority in it. Fourth, rules and regulations. Fifth, career path orientation, and Sixth, efficiency [12]. The six characteristics that are a summary of what has been stated by Weber are characteristics where bureaucracy can be said as the ideal type of organization, then if these characteristics can be carried out then an organization can carry out its duties optimally and be able to work optimally to help the government in a region.

\section{a. Division of Work and Specialization}

In carrying out government functions and carrying out all activities related to administration and services to the village community, special specialization in the field of work or division of work in each village is needed. The village head has the authority to propose the formation of a village management organizational structure, this should be able to be used by the village head in finding or putting competent people to occupy the position of village government.

In Law No. 6 of 2014 concerning the fifth part of the village article 48 has been written related to the village apparatus consisting of: village secretary, regional executor, and technical implementer [4]. The village government is appointed by the village head by conducting consultations and considerations with the Head of the Sub-District and the Mayor or Regent. The village official is tasked with assisting the village head in carrying out his duties and authority.

\section{b. Impersonal orientation}

Impersonal orientation in this case can be interpreted as an effort of professionalism in work by prioritizing public interests rather than personal or personal interests. Work professionalism must be considered in the administration and service implementation process, especially in the village realm that is still thick with cultural values and customs that bring a situation of kinship and kinship closeness. It is important to realize that the village government works for common interests, the interests of the village community at large are not to provide services to relatives of village government members or even village heads.

Professionalism of work is a work challenge that has a difficult task, not only in the scope of behalf of relatives or family. In the world of work there needs to be an impersonal orientation in which all actions or activities are not linked to personal interests, sanctions are applied uniformly and without personal feelings to avoid involvement with individual personalities and personal preferences of members [15]. However, in the work environment, especially in the government environment, of course it cannot be denied that the application of impersonal 
orientation or the exclusion of personal relationships that often occur between a person who has a high position to those who are under him in a work environment.

In the administration of village governance, it turns out that there is still a lot of corruption committed. Corruption is widespread, including the exclusion of impersonal factors at work. The number of perpetrators of corruption in the village was also carried out by relatives and even wives of village officials. In accordance with the presentation of Egi Primayogha as ICW researcher explained that: "Of the 139 actors, 107 of them were village heads. In addition, other corruption perpetrators are 30 village officials and 2 heads of village heads" [4].

\section{c. Hierarchy / Organizational Structure}

In a bureaucratic organization there needs to be a fairly clear organizational structure, this is intended so that there is a clarity about the level of accountability between governments working in a bureaucracy as in the regional secretary bureaucratic organization. In a bureaucratic environment, there should be someone who acts to occupy a position either as a leader, staff, or as an executive. This clear division or organizational structure is certainly important so that each of the individuals who become the government in it can understand what they are doing will be reported or accounted for to whom later.

The existence of a clear organizational structure or hierarchy is very important to note so that each division of work can be carried out with full accountability. All village officials in carrying out their duties and authority, they are responsible to the village head. Such a mechanism must be able to run according to procedure so that an accountable government can be held.

\section{d. Rules or Regulations}

In carrying out the process of carrying out tasks or the continuity of a bureaucratic organization in carrying out its duties, it certainly requires a clear regulation or legal basis. This clear regulation will later be used as a reference or basis for carrying out their duties and responsibilities so that there is no confusion and there is clear legitimacy in carrying out the tasks assigned. Regulation on villages has been regulated in Law No. 6 of 2014 concerning Villages. The village law has regulated everything including village governance, but the village government also has the authority to make village regulations, this authority can be used to regulate the main tasks and functions of the existing village administration or government $[4 ; 6]$.

Regulations regarding the main tasks and functions or standard operating procedures are needed so that village officials have clear references and guidelines in carrying out their duties. The regulation is also intended so that there is no overlapping authority in carrying out the task.

\section{e. Career Path Orientation}

Career path is an award which is commonly called the promotion of position in the work environment. Giving a promotion or a clear career path is a tribute to village officials who have good performance in carrying out their duties [16]. This 
career orientation orientation can also be a motivation for village officials to be able to work well and optimally to be able to get a promotion, so that the quality of work of regional officials can improve and have an impact on seriousness in providing services and improving community welfare. However, in practice this has not been widely applied in many villages.

\section{Conclusion}

Based on the explanation above, this paper leads at least to the following conclusions:

First, the granting of authority to the village government must be balanced with good and ideal and competent village governance. The authority granted to villages in carrying out development and utilization of village fund budgets is prone to being misused so there is a need for the concept of good village governance. Secondly, in the village government authority in Indonesia there are still many deviations done both by the village head as well as the village government and relatives. Third, the sustainability of village governance is very influential and has a significant impact on the course of village development and services to the village community.

\section{REFERENCES}

[1] Agustino L. Konsep Dasar Kebijakan Publik [The Basic Concepts of Public Policy]. Badung: Alfabeta; 2012 (In Indon.).

[2] Astuti W. Peluang dan tantangan penerapan egovernance dalam konteks otonomi daerah [Opportunities and Challenges in Implementation of E-governance in the Context of Regional Autonomy]. Surabaya: Universitas Airlangga; 2005 (In Indon.).

[3] Dwiyanto A. Mengembalikan Kepercayaan Publik Melalui Reformasi Birokrasi [Restore Public Trust through Bureaucratic Reform]. Jakarta: Gramedia Pustaka Utama; 2017 (In Indon.).

[4] Pasolong H. Teori Administrasi Publik [The Theory of Public Administration]. Bandung: Alfabeta; 2018 (In Indon.).

[5] Mustafa D. Birokrasi Pemerintahan [Government Bureaucracy]. Bandung: Alfabeta; 2017 (In Indon.).

[6] Robbins S.P. Alih bahasa: Jusuf Udaya [Organization Theory: Structure, Design, and Application]. Jakarta: Arcan; 2015 (In Indon.).

[7] Wibawa S. Administrasi Negara Isu-isu Kontemporer [State Administration: Contemporary Issues]. Yogyakarta: Graha Ilmu; 2016 (In Indon.).

[8] Viky A.H., Tistry R.P., Deva P., Nandy J., Lidya T.A. Pramudita. Menggagas Revolusi Mental Birokrasi Melalui Konsep (Competitive Agile Leadership) [Pramudita. Initiate A Mental Revolution Bureaucracy through the Concept of Competitive Agile Leadership]. Jurnal Birokrasi \& Pemerintahan Daerah. 2020; 2 (1): 29-37. DOI: 10.15575/jbpd.v2i1.8050 (In Indon.).

[9] Setiawan R. Peranan Etika Aparatur Sipil Negara Dalam Pelayanan Publik Pada Dinas Kependudukan Dan Catatan Sipil (Disdukcapil) Kota Bandar Lampung [The Role of the Ethics of the Civil Apparatus of the State in Public Service at Population and Civil Registration Agency (Disdukcapil). The City of Bandar Lampung]. Jurnal Kebijakan \& Pelayanan Publik (e-JKPP). 2016; 2 (2): 46-57. URL: http://jurnal.ubl.ac.id/index.php/ejkpp/article/view/803. Accessed: 15.06.2020 (In Indon.). 
[10] Widodo J. Membangun Birokrasi Berbasis Kinerja [Build Bureaucratic-based Performance]. Malang: Bayumedia Publishing; 2012 (In Indon.).

[11] Santoso P. Administrasi Publik Teori dan Aplikasi Good Governance [Public Administration Theory and the Application of Good Governance]. Bandung: Rafika Aditama; 2008 (In Indon.).

[12] Sedarmayanti. Reformasi Administrasi Publik, Reformasi Birokrasi, dan Kepemimpinan Masa Depan [The Reform of Public Administration, Bureaucratic Reform, and the Future Leadership]. Bandung. Refika Aditama; 2011 (In Indon.).

[13] Thoha M. Birokrasi Pemerintah Indonesia di Era Reformasi [The Bureaucracy of the Government of Indonesia in the Reform Era]. Jakarta: Kencana Prenada Media Group; 2011 (In Indon.).

[14] Yusriadi A.H., Ihsan A. Bureaucratic Reform in Public Service: A Case Study on the One Stop-Integrated Service. Mediterranean Journal of Social Sciences. 2017; 8: 253258. DOI: 10.5901/mjss.2017.v8n2p253

[15] Farida I., Setiawan R. Leadership in Cope with Prostitute in Social Department of Bandar Lampung. International Journal of Social Sciences and Development. 2018; 2 (1): 1-8. DOI: 10.24967/saburaiijssd.v2i1.325

[16] Prasetyo A.G. Mengintegrasikan Reformasi Birokrasi dengan Inovasi Sektor Publik [Integrate Bureaucratic Reform with Innovation in the Public Sector]. Jurnal Analisis Kebijakan. 2017; 1 (1). URL: https://www.academia.edu/35227638/Mengintegrasikan_Reformasi_ Birokrasi_dengan_Inovasi_Sektor_Publik. Accessed: 15.06.2020 (In Indon.).

\title{
Article history:
}

The article was submitted on 23.06.2020.

The article was accepted on 05.08.2020.

Научная статья

\section{Оптимизация осуществления сельского управления в Индонезии}

\author{
Р. Сетаван, Е. Мелинда \\ Университет Бандар Лампунг \\ Пагар Алам No. 29 Лабухан Рату, Лампунг, Индонезия, 35142
}

Аннотация. Данное исследование анализирует Закон Республики Индонезия № 6 от 2014 года о деревнях, в соответствии с которым деревни являются движущей силой национального развития. Появление данного закона определяет реальное положение и полномочия сельского самоуправления. Закон также регулирует государственную политику в отношении распределения средств, что позволяет органам сельского самоуправления использовать их для развития своего потенциала. Кроме того, сельская политика Индонезии обеспечивает источники средств, а также предоставляет органам самоуправления достаточные полномочия для улучшения благосостояния деревенских общин. Авторы отмечают, что правила, которые обеспечивают значительные полномочия и ответственность сельского самоуправления на уровне деревень, должны быть сбалансированы, чтобы обеспечить обязательства по надлежащему управлению. Однако при реализации этой политики выясняется, что по-прежнему имеются случаи незаконного присвоения сельскохозяйственного фонда аппаратом сельского управления. В статье представлен анализ важности сельского самоуправления и реализации Закона Республики Индонезия № 6 от 2014 года с использованием теории рациональной бюрократии, предложенной М. Вебером.

Ключевые слова: деревенское самоуправление, закон, оптимизация, бюджет, Индонезия 


\section{История статьи:}

Статья поступила в редакцию: 23.06.2020.

Статья принята к публикации: 05.08.2020.

\section{Информация об авторах:}

Рефли Сетаван - магистр государственного управления, преподаватель кафедры государственного управления университета Бандар Лампунг (Индонезия) (ORCID ID: 0000-0003-0719-1287) (e-mail: refly@ubl.ac.id).

Эсти Мелинда - магистр менеджмента, преподаватель кафедры государственного управления университета Бандар Лампунг (Индонезия) (e-mail: estimelinda1987@gmail.com)

\section{Information about the authors:}

Refly Setiawan - Master of Public Administration, Lecturer of the Department of Public Administration, University of Bandar Lampung (Indonesia) (ORCID ID: 0000-0003-07191287) (e-mail: refly@ubl.ac.id).

Esti Melinda - Master of Management, Lecturer of the Department of Public Administration, University of Bandar Lampung (Indonesia) (e-mail: estimelinda1987@gmail.com).

\section{Для цитирования:}

Setiawan R., Melinda E. Optimization of the Implementation of Village Government in Indonesia // Вестник Российского университета дружбы народов. Серия: Государственное и муниципальное управление. 2020. Т. 7. № 4. С. 352-360. DOI: 10.22363/2312-83132020-7-4-352-360

\section{For citation:}

Setiawan R., Melinda E. Optimization of the Implementation of Village Government in Indonesia. RUDN Journal of Public Administration. 2020; 7 (4): 352-360. DOI: 10.22363/ 2312-8313-2020-7-4-352-360 